Article

\title{
Digitalized Sports Products and Various Generations in the Era of Industry 4.0
}

\author{
Marcin Leszczyński ${ }^{1}$, Adam Metelski ${ }^{2}$ and Aleksandra Rabczun ${ }^{1, *(1)}$ \\ 1 Department of Information Economics, Poznan University of Economics and Business, \\ 61-875 Poznań, Poland; marcin.leszczynski@ue.poznan.pl \\ 2 Department of Education and Personnel Development, Poznan University of Economics and Business, \\ 61-875 Poznań, Poland; adam.metelski@ue.poznan.pl \\ * Correspondence: aleksandra.rabczun@ue.poznan.pl
}

Citation: Leszczyński, M.; Metelski,

A.; Rabczun, A. Digitalized Sports

Products and Various Generations in the Era of Industry 4.0. Sustainability 2022, 14, 95. https://doi.org/ $10.3390 /$ su14010095

Academic Editor: Franklin G. Mixon

Received: 28 October 2021

Accepted: 18 December 2021

Published: 22 December 2021

Publisher's Note: MDPI stays neutral with regard to jurisdictional claims in published maps and institutional affiliations.

Copyright: (C) 2021 by the authors. Licensee MDPI, Basel, Switzerland. This article is an open access article distributed under the terms and conditions of the Creative Commons Attribution (CC BY) license (https:// creativecommons.org/licenses/by/ $4.0 /)$.

\begin{abstract}
In modern times of Industry 4.0, digital solutions are used in an increasing number of branches of the economy, and this also applies to sports. Generational cohorts provide a way to understand how different life experiences affect people's views of the world. There is a new growing group of sports fans-modern fans - who have been functioning in the digital world since birth, and therefore have their specific behavioral patterns, habits, and expectations. For this reason the sports industry must adapt properly to continue to develop. This article aims to identify how consumers representing various generations on the Polish market consume sports products provided by digitized channels. The study focused on three areas: the source of information about the sport, devices on which consumers watch sports and the evaluation of the attractiveness of sports products (full games, game highlights and behind the scenes). The study was conducted in the form of an online survey in 2021, and 581 Polish volleyball fans took part in it. The results indicate that younger generations are more likely to get sports information from social media and less likely to watch games on TV than older generations.
\end{abstract}

Keywords: digitalisation; Industry 4.0; sports; modern fans; volleyball

\section{Introduction}

In Industry 4.0, digital solutions are used in an increasing number of branches of the economy. Consumers have tools such as computers, smartphones, and tablets that allow them to obtain interesting content at a place and time of their choice. These tools are slowly replacing traditional television, especially among younger generations. This is evidenced by the fact that the frequency of TV use is lower than smartphones and laptops [1]. Television is the main source of news for $65 \%$ of consumers, while the Internet plays such a role for $82 \%$ [2]. This trend is particularly evident in sports, where consumers under 50 are more likely to watch sports events online than on TV [1]. This is also visible in the advertising market, of which the Internet covers over $52 \%$, which is twice as high as television [3]. Consumers are also more and more open to new solutions in sports, i.e., non-live content, highlights/short-form content, or team/athlete-generated content $[1,4]$.

Changing trends in consumption patterns of sports products lead to increasing awareness of sports organizations and adapting to new ways of satisfying market needs. These organizations create a new digitized space for the consumption of sports products indirectly (for example through digital broadcasting rights), but also directly, i.e., by delivering their content through digitized channels. However, it should be noted that despite the dynamic digitization of the sports industry, there are at least two variables that may determine success. The first is the specificity of a given market, and the second is the generation that a given consumer represents. Markets have varying degrees of sophistication in terms of the progress of digitization of the economy. In Poland in 2020, television advertising expenditure was 3 percentage points higher than on the Internet. The Internet accounted 
for $41 \%$ of the advertising market, which is 11 percentage points lower than the global market. On the other hand, television in Poland accounted for $44 \%$ of the advertising market, which is 16 percentage points higher than on the global market [3].

Differences in consumption preferences for sports products are strongly related to the age of the consumer. Consumers representing Generations $\mathrm{Y}$ and $\mathrm{Z}$ are more open to new consumption models compared to Generations $\mathrm{X}$ and BB (Baby Boomers). Moreover, some differences can also be observed for example between Generations $Y$ and $Z$ : representatives of Generation $\mathrm{Z}$ are less inclined to watch sport live, and more inclined not to watch it at all [5]. Interestingly, for only $47 \%$ of consumers aged $18-24$, television is the main source of news, while for people over 55 years old this is as high as $76 \%$ [2]. Therefore, this study aims to identify how consumers representing various generations in the Polish market consume sports products, considering such items as (1) source of information on sports; (2) devices on which consumers watch sports; (3) evaluation of the attractiveness of sports products. It is important to note that past studies of sports product consumers show that traditional sources of sports information are becoming less appealing and are being replaced by new digitized technologies, with younger generations taking control of sports discussion in new media, disregarding traditional sports journalists [6]. Therefore, an additional objective of the study is to verify whether younger generations are getting more information from new digitized sources such as social media. Literature also indicates that Generation $\mathrm{Z}$ shows strong technological behaviors and uses new technological solutions to consume sports products [7]. Similar conclusions can be reached by analyzing reports, in which there is a clear tendency of generation $\mathrm{Z}$ to be less interested in traditional channels for the consumption of sports products $[3,8,9]$. Therefore, another objective of the study is to determine the differences between generations in terms of the choice of devices that allow the consumption of sports products traditional e.g. TV set, or based on new technologies, e.g., smartphones, tablets and computers). Attention should be paid to the growing interest in new types of sports product that can be obtained thanks to the digitization of consumption channels. This process is particularly visible among young consumers $[1,10]$. Therefore, the next objective of the study is to verify the preferences of different generations towards the three types of sports products that can be obtained through digitized channels, i.e., full games, highlights and behind the scenes. The study involved 581 volleyball fans. It is worth noting that in Poland volleyball is one of the most popular team sports. Participants were divided into four generations: Baby Boomers (BB), Generation X, Generation Y, and Generation Z.

\subsection{Industry 4.0}

The term Industry 4.0 embraces a wide array of interdisciplinary technologies, and all have different levels of maturity and market availability. For this reason, Industry 4.0 facilitates digitization, automation, and process integration along value chains [11]. For Ghobakhloo [12], the term Industry 4.0 refers to key design principles and technology trends, but also architectural design. He defined it as an integrative system of value creation. Manufacturers have to get used to this new reality, although there is no one best strategy for all companies, and each firm needs a roadmap that should respect the company's organizational culture [12]. For many countries, Industry 4.0 offers a unique chance to further modernize their economies and climb up the value chains. In consequence, they may become recognized as highly developed countries. However, Industry 4.0 can materialize only in a specific context, when an elementary digital infrastructure is provided by state or private investors, required skills and capabilities are nurtured and safeguarded, and the application of modern technologies is properly prompted [13].

The concept of the digital economy is relatively fresh, appearing in the mid-1990s (there is no possibility of setting a specific date). The first definitions prepared by experts were presented by the OCED in 2012 and the European Commission in 2013 [14]. Both entities identified the digital economy with the internet economy. The specificity of the digital economy (under Industry 4.0) is determined by the interrelated processes of data 
modification and networking. In the digital economy, their intensity and prevalence are growing, and their nature is changing as a result of implementation of new technologies for collecting, processing, analyzing and using data. This phenomenon is accompanied by the development of algorithms supported by artificial intelligence, which results in increasing personalization, i.e., the production of goods, the production of content (and marketing), or the provision of services better adapted to the needs and expectations of individual recipients. The digital economy is materializing as a result of myriad processes of digital transformation that change the way consumers and workers, markets and enterprises, and other organizations-including the state and the global economy-function.

Year by year, digital transformation is an increasing challenge for governments and international institutions. Governments are responsible for ensuring a stable and accessible infrastructure, which is a necessary condition for the functioning of the digital economy, for creating an institutional and legal environment that fosters innovation and integration of digital technologies, and for creating an educational system that prepares society for transformation. Comprehensive strategies have already been developed in many countries, including support for the digitization of industry, the dissemination of competencies through changes in education programs, and many activities to combat digital exclusion. In Poland, the activities of the national government are supported by various initiatives of the European Union which finances the implementation of projects aimed at digitization. However, the regulations aimed at securing digital content turn out to be problematic [14]. The key drivers for the development of the digital economy today are:

- Internet of Things and Internet of Everything,

- hyperconnectivity plus applications and services based on cloud computing,

- big data Analytics and Big-Data-as-a-Service,

- automation and robotization,

- multi-channel and omnichannel distribution models of services [15].

It should be made clear that digital economy and digitization are not identical concepts. Digitization in the context of the digital economy is a series of activities aimed at increasing the availability of the Internet and its resources, and implementing electronic mechanisms in public administration. A material manifestation of it is, for example, the possibility of submitting various applications to a public administration via the Internet. In contrast, digitization sensu stricto is the process of converting analogue to digital resources to make them available through digital means. Digitization includes preparing documents for digital transformation, formatting, describing (collecting metadata), and making documents available via the network. Digitization is an element of the digital economy, the goal of which is to develop e-sources and e-services [16]. Digitization prompts researchers to analyze the accelerating phenomenon of the migration of economic activity to the digital world. This entails several benefits and dangers that still receive too little attention in the discourse [17].

In terms of the digitization index, Poland fares quite poorly compared to some European Union countries. At the same time, economic progress in the digitization field is better than the social field. This means that companies are digitizing much faster than consumers, and in consequence the 'scissors' of supply and demand are created. Financial sector enterprises stand out against this background, and their high digitization is related to the high competitiveness of services in this sector. A characteristic feature of the digitization of the Polish financial sector are the so called "frog jumps", i.e., omission of unnecessary stages in technological progress and quick implementation of novelties. The reason for the low digitization of other sectors is the fact that most companies are micro- and small companies with no possibility of investing in digitization. Compared to Europe as a whole, Poland has an overrepresentation of business entities that do not invest more in IT than at a minimal level [17]. 


\subsection{Various Generations of Sports Consumers}

Generational cohorts provide a way to understand how different experiences (such as technological, economic, and social shifts) interact with the life-cycle and aging process to shape people's views of the world [18]. In the literature on this subject, the following generations are usually distinguished: Silent Generation, Baby Boomers, Generation X, Generation Y, and Generation Z [18-21]. Generational cut-off points are not identical in all resources, but they should be viewed primarily as tools for analysis. In this study, it was decided to check how representatives of different generations consume sports products.

It is widely believed that a fan's relationship with his or her favorite club or player is much deeper than a typical consumer relationship: fans are often emotionally attached to the object of their sympathy [22,23]. It should be noted, however, that the loyalty and behaviour of sports fans are much more complex than the conventional belief that fans are faithful to one club throughout their lives [24]. In sports marketing, fans are treated as a diverse group whose representatives can be found in every socio-economic class [25,26]. It is also necessary to mention that there is a new group of sports fans-modern fans who have been functioning in the digital world since birth, and therefore have their specific behavioral patterns, habits, and expectations [8]. Modern fans want to be informed and involved in the decision-making processes that are important for the club, and are ready to solve its problems, or even support it in case of a financial crisis. They seek access to information at the time at which they deem appropriate from the devices they are using at that moment. Fans want to know how the members of the team spend their free time and what they do when they do not train or play matches. Therefore, this group of fans requires personalized messages sent through various channels.

Prensky [27] indicated two basic social groups: digital natives and digital immigrants. Young people (born after 1980) are "natives" living in the digital world. For them, cyberspace is a completely natural environment to which they do not have to adapt but rather perceive it as "home". Contrarily, a digital immigrant is a person who was born before the dynamic development of Internet technologies took place (before 1980), and probably had to (or wanted to) adapt to these technologies at some stage in their life. This division is important from the point of view of sports clubs, and even more broadly the entire sports industry. In 2013, the number of Internet "natives" began to exceed the number of traditional consumers attached to the existing forms of marketing communication [8]. Sports clubs understood that this could mean gradual changes in the audience, considered both as people sitting in the stadium and fans watching a broadcast. In one of the studies in which 470 representatives of the sports industry were surveyed, the results indicated that the change in consumer behaviour within the young generations is the most important threat facing the sports industry [4]. It is therefore worth analyzing which are the basic dimensions of consumer behaviors among the young people that are so different. First of all, they are related to the increased use of smartphones and other devices connected to the Internet [8]. 74\% of fans under 35 consume sports content on smart devices such as smart TVs, laptops, desktops, iPads, compared to $55 \%$ of fans over 35 [9]. This is part of a wider phenomenon that characterizes 4.0 Industry which shows a change in the methods of searching for and consuming content among consumers.

In 2020, the average daily time spent in front of the TV among consumers aged 16-29 amounted to nearly $2 \mathrm{~h}$ and was over 3.5 times lower than among people over 50 [3]. This trend is also visible in the sports industry. Sports news is very popular in traditional media [28], but consumers under the age of 50 are more likely to watch football games online than on TV. Consumers aged 20 to 34 use online resources almost three times more often than traditional TV. On the other hand, among consumers over 50 years old, twice as many respondents prefer traditional television to online resources [1]. All these factors indicate how big are the changes that await the sports industry. 


\subsection{Digitized Sports Products}

A sports product may be a good or service. It can include, among others: sports events, sports tourism, sports training, sports equipment, sports clothing, access and broadcasting rights for the event, or a ticket to a sports event [29]. A sports product has certain characteristics that distinguish it from other products on the market. First of all, consumer experiences are completely subjective, because a well-organized event or highquality content (e.g., a video clip of the event or backstage of the event) may be rated poorly if the team loses. Secondly, the sports product is unpredictable-consumers do not know the result of the match before its end, and thus the product is not well known before the purchase. It has to be added that unpredictability in sports is a factor that determines the attractiveness of a sports product, therefore the creators of sports products focus on the experience of fans during the event $[30,31]$.

It can be concluded that younger generations are characterized by a different model of consumption of sports products which is based on the use of digitized channels of searching and consuming content. It should be noted that in some cases digitization of sports products, e.g., match highlights, may eliminate one of the key factors of sport attractiveness, i.e., unpredictability. It is also worth adding that the use of digitized channels to deliver content to consumers can be included in the category of marketing innovation in Industry 4.0. Marketing innovation can be understood as the implementation of a new method of promotion, valuation, or sale of products/services [32]. Processes in the area of interaction with fans include, among others: minimizing the boundaries between the event watched online and offline, increasing the digital presence of sport, and developing opportunities for interaction with stakeholders through websites, mobile applications, and social media [33]. In this situation, consumption of sports products does not only take place on the day of a given sporting event, but through the digitized channels stakeholders receive personalized content in a place and time that is appropriate for them. The process of digitization of sports products also leads to the democratization of interactions between stakeholders, as they do not have to be passive consumers of content and may become participants in many processes that take place in a given organization [33].

Digitizing sports products also provides greater freedom to view content such as nonlive content, highlights/short-form, or team/athlete-generated content. Non-live content is consumed three times more often by respondents aged 16-35 compared to respondents aged over 36 [1]. What is more, members of Generation $\mathrm{Z}$ are half as likely as Millennials to watch live sports regularly and twice as likely to never watch it [5]. Another interesting fact is that about half of young (18-34 years old) NFL, NBA and MLB fans prefer watching highlights over a full game as opposed to fans aged 35 and more who still like to tune in for the whole event [10]. This may indicate that digital channels for acquiring sports content have a high growth potential [1].

The potential for digitized sports products is also evidenced by the value of media rights. Digital sports media rights have the highest potential growth in the next few years, projected at $11.5 \%$. This is nearly four times higher than TV broadcast rights which have an average potential of $3.2 \%$ [1]. The importance of channel digitization to deliver content to consumers is also visible in the advertising market, where the Internet in 2020 accounted for over $52 \%$ of the global advertising market, which is three times higher than in 2010. In the case of TV, in 2020 it was $28 \%$, while in 2010 it was close to $40 \%$ [3]. The advertising market in Poland in 2020 looked differently; in this case, TV was the leader with a share of $44 \%$, and the Internet was in the second place with $41 \%$, although Poles use the Internet twice as often as TV on a daily basis [3]. The importance of digitization and changes in consumer behaviour is also considered to be a threat to the sports industry, where the category of piracy/illegal streaming was indicated in 2020 by as many as $41 \%$ of respondents [4].

Many sports fans are no longer interested in the game alone-they crave the kind of exclusive and shareable experiences that can be amplified by technology. New technologies can also increase fan engagement by tailoring experiences to the individual fan preferences [34]. It should be noted that the COVID-19 pandemic has hit the sports world 
particularly hard. The pandemic had the greatest impact on direct matchday revenue, as stadiums were closed to fans or could be only partially filled. In cases when stadiums were closed and there was no possibility of typical contact between clubs and fans, other platforms of communication such as social media have become even more important [35]. Technology platforms such as Facebook, Amazon, and Google show the greatest potential in this area [1]. The largest number of respondents $(86.1 \%)$ indicate that social media would be characterized by the highest growth as channels for acquiring sports content [4]. Digitalization of sports products based on the use of new technologies may condition the ways in which different generations obtain information about sports and consume sports products. The results of previous studies indicate that the way people obtain information and consume sports products is changing as a result of technology development [6,7]. The provision of fan interaction provided by new technologies results in a reduced importance of traditional channels such as television and a smaller role for traditional journalists. Technological developments themselves can provide new emotional experiences that consumers seek [6]. Emotional consumption, technology-driven, peer pressure, community-driven, and fan engagement are key characteristics of generation $Z$, most of which also apply to the consumption of sports products [7]. Generation Z is more likely to use technology due to the complement of sports experiences by the other previously mentioned characteristics of this generation. Generation $\mathrm{Z}$ has a greater preference for consumption through new technologies and sports products that are not oriented towards new technologies. This is the case when generation $\mathrm{Z}$ uses new technology in the process of consuming sports products because it allows them, for example, to access information more easily and quickly and to interact with their peers [7].

\section{Materials and Methods}

The study was conducted in the form of an online survey in 2021 among Polish volleyball fans. The survey was conducted in cooperation with one of the best Polish volleyball clubs-Trefl Gdańsk. This club sent a link to the survey to all people in its fans' email database and shared the link to the survey on its social media profiles. Every fan who follows the club's profile on social media could take part in the survey and the database contained people who had ever bought a season ticket for matches, bought a ticket online, or took part in earlier club marketing campaigns. It is worth adding that in Poland volleyball is one of the most popular sports, and the national team is one of the best in the world [36]. This was one of the main reasons why the authors decided to select volleyball fans as the study group, and the second reason was the willingness to cooperate of one of the best clubs-Trefl Gdańsk.

Overall 581 people participated in the study. Among the respondents, $61.1 \%$ were women, 38.2\% were men, and 7 people did not want to answer this question. As for the age of the respondents, the average was 33.19 years, with the oldest 74 years old and the youngest 13 years old. The respondents were divided into four groups according to their generation: Baby Boomers (BB), born in 1946-1964, Generation X (1965-1979), Generation Y (1980-1994) and Generation Z (born in 1995 and later). No representative of the Silent Generation took part in this study. As a result of such division, the following group sizes were obtained: BB: 36 (6\% of the total), X: 101 (17\%), Y: 288 (50\%), and Z: 153 (27\%). The overall share of generations in Poland in 2017 was as follows: Silent Generation 10.6\%, BB $22.7 \%$, X 20.5\%, Y 22.8\% and Z 23.4\% [37]. Therefore, comparing our study group with the general population in Poland, it has to be stated that there is a lack of representatives of the older generations, and generation $\mathrm{Y}$ is over-represented. For this reason, it is not a representative study for the entire country, and its results are only intended to present a certain part of reality.

The following questions were analysed in the study, which were part of a larger questionnaire: (1) What is your main source of information about the volleyball? (2) On which device do you most often watch volleyball matches?; (3) What is the most attractive sports material to you? Overall, the questionnaire consisted of 32 questions and its subject matter 
mainly concerned the consumption of sports products in modern times, including the impact of COVID-19. The authors of this article were responsible for creating the questionnaire. The study proposed hypotheses that representatives of different generations consume sports products in different ways, in particular in the case of the source of information about the sport, devices on which consumers watch sports and the evaluation of the attractiveness of three types of content: full games, game highlights and behind the scenes. Descriptive statistics and statistical tests (Chi-square) were used in the study. Microsoft Excel 2019 and IBM SPSS Statistics 26 were both used to process the quantitative data.

\section{Results}

At the outset, it was decided to check where representatives of different generations most often look for information about their favorite sports club. BB representatives most often use the club's website for this purpose, while the other three generations prefer the club's social media. Detailed data are presented in Table 1.

Table 1. Generations and the main source of information.

\begin{tabular}{|c|c|c|c|c|c|c|}
\hline Generation & Club's Website & Club's Social Media & Press & TV & Local Websites & Sports Websites \\
\hline $\mathrm{BB}$ & $\begin{array}{c}52.9 \% \\
(n=18)\end{array}$ & $\begin{array}{c}8.8 \% \\
(n=3)\end{array}$ & $\begin{array}{c}0.0 \% \\
(n=0)\end{array}$ & $\begin{array}{c}2.9 \% \\
(n=1)\end{array}$ & $\begin{array}{l}14.7 \% \\
(n=5)\end{array}$ & $\begin{array}{l}20.6 \% \\
(n=7)\end{array}$ \\
\hline$X$ & $\begin{array}{c}28.7 \% \\
(n=29)\end{array}$ & $\begin{array}{c}45.5 \% \\
(n=46)\end{array}$ & $\begin{array}{c}0.0 \% \\
(n=0)\end{array}$ & $\begin{array}{c}3.0 \% \\
(n=3)\end{array}$ & $\begin{array}{c}8.9 \% \\
(n=9)\end{array}$ & $\begin{array}{c}13.9 \% \\
(n=14)\end{array}$ \\
\hline $\mathrm{Y}$ & $\begin{array}{c}7.7 \% \\
(n=22)\end{array}$ & $\begin{array}{c}75.7 \% \\
(n=215)\end{array}$ & $\begin{array}{c}0.4 \% \\
(n=1)\end{array}$ & $\begin{array}{c}0.0 \% \\
(n=0)\end{array}$ & $\begin{array}{c}3.5 \% \\
(n=10)\end{array}$ & $\begin{array}{c}12.7 \% \\
(n=36)\end{array}$ \\
\hline $\mathrm{Z}$ & $\begin{array}{c}6.6 \% \\
(n=10)\end{array}$ & $\begin{array}{c}80.9 \% \\
(n=123)\end{array}$ & $\begin{array}{c}0.0 \% \\
(n=0)\end{array}$ & $\begin{array}{c}1.3 \% \\
(n=2)\end{array}$ & $\begin{array}{c}1.3 \% \\
(n=2)\end{array}$ & $\begin{array}{c}9.9 \% \\
(n=15)\end{array}$ \\
\hline
\end{tabular}

Source: own elaboration.

Interestingly, only one respondent indicated the press as the main source of information, which demonstratively proves the diminishing importance of this media in sport. The differences between the analysed groups turn out to be statistically significant, as evidenced by the following results of the Chi-Square Test: X2 $(15, N=573)=126.06, p<0.001$. Another aspect analysed was the device on which the representatives of each generation watch matches most often. For all generations, the most frequently used device was the TV set. However, in the two younger generations, the proportion was about 20 percentage points lower than in the older generations. Younger generations relatively often watch matches on computers also (almost every fifth person) and smartphones (almost every tenth person). The tablet turned out to be the least popular device. The differences in the responses of representatives of different generations turned out to be statistically significant, as evidenced by the Chi-Square Test: X2 $(9, N=574)=24.66, p=0.003$. Detailed responses of the respondents are presented in Table 2.

Table 2. Generations and devices most frequently used to watch matches.

\begin{tabular}{ccccc}
\hline Generation & TV & Smartphone & Tablet & Computer \\
\hline \multirow{2}{*}{ BB } & $94.4 \%$ & $0.0 \%$ & $0.0 \%$ & $5.6 \%$ \\
& $(n=34)$ & $(n=0)$ & $(n=0)$ & $(n=2)$ \\
$\mathrm{X}$ & $90.0 \%$ & $4.0 \%$ & $0.0 \%$ & $6.0 \%$ \\
& $(n=90)$ & $(n=4)$ & $(n=0)$ & $(n=6)$ \\
$\mathrm{Y}$ & $70.3 \%$ & $9.8 \%$ & $1.7 \%$ & $18.2 \%$ \\
& $(n=201)$ & $(n=28)$ & $(n=5)$ & $(n=52)$ \\
$\mathrm{Z}$ & $74.3 \%$ & $9.9 \%$ & $0.7 \%$ & $15.1 \%$ \\
& $(n=113)$ & $(n=15)$ & $(n=1)$ & $(n=23)$ \\
\hline
\end{tabular}

Source: own elaboration. 
The third aspect analysed was related to the most attractive sports product. It was decided to list the following three materials: entire matches, match highlights, and behindthe-scenes events. Responses to this question are presented in Table 3.

Table 3. Generations and the most attractive sports materials.

\begin{tabular}{cccc}
\hline Generation & Full Games & Game Highlights & Behind the Scenes \\
\hline \multirow{2}{*}{ BB } & $94.3 \%$ & $2.9 \%$ & $2.9 \%$ \\
& $(n=33)$ & $(n=1)$ & $(n=1)$ \\
X & $95.0 \%$ & $1.0 \%$ & $4.0 \%$ \\
& $(n=96)$ & $(n=1)$ & $(n=4)$ \\
Y & $83.5 \%$ & $3.5 \%$ & $13.0 \%$ \\
& $(n=238)$ & $(n=10)$ & $(n=37)$ \\
Z & $83.6 \%$ & $3.3 \%$ & $13.2 \%$ \\
& $(n=127)$ & $(n=5)$ & $(n=20)$ \\
\hline
\end{tabular}

Source: own elaboration.

The vast majority of respondents stated that full matches are the most attractive. It should be noted, however, that among the younger generations the percentage was about 10 percentage points lower than among the older generations. Interestingly, representatives of the younger generations also stated that behind-the-scenes events are relatively interesting, whereas in the case of older generations only a few individuals were interested in this type of content. However, the differences in the responses of different generations did not turn out to be statistically significant, as evidenced by the following results of the Chi-Square Test: $\mathrm{X} 2(6, N=573)=11.66, p=0.070$.

\section{Discussion}

In Industry 4.0, digital solutions are used in an increasing number of branches of the economy, and this also applies to sports. Nowadays consumers have tools such as computers, smartphones, and tablets that allow them to obtain interesting content at a place and time of their choice. It can be noticed that consumers of younger Generations $Y$ and $\mathrm{Z}$ are more open to new consumption models, in contrast to older Generations X and BB. There is also a new group of sports fans-modern fans, who have been functioning in the digital world since birth, and therefore have their own specific behavioral patterns, habits, and expectations. These changes are important from the point of view of sports clubs, and more broadly the entire sports industry. Sports clubs need to understand that these phenomena can lead to gradual changes in the audience in and outside of the stadium.

In this study, it turned out that BB representatives most often use the club's website as the main source of information about their favorite club, while the other three generations prefer the club's social media. This result confirms previous research findings [6] that younger generations obtain information about sports from social media more often than from other media. The result shows how trends in obtaining information in individual people are changing. Only a few decades ago, the most popular source of information was the press, the role of which is becoming negligible today. In turn, for over a dozen years, a huge increase in the popularity of social media has been observed. Interestingly, social media itself is constantly developing and changing. These changes undoubtedly show how important a process is digitization and how important it is for sports organizations to adapt to the requirements of contemporary sports consumers. Without observation and adaptation to these changes, sports organizations will not develop, because the old solution will not always satisfy the needs of young consumers.

For all generations, the most frequently used device to watch sports matches was the TV set. However, in the two younger generations ( $Y$ and $Z$ ), the percentage was about 20 percentage points lower than in the older generations. Younger generations relatively often also watch matches on computers and smartphones. This result on the one hand confirms previous research findings that generation $\mathrm{Z}$ uses new technological solutions in the process of consuming sports products [7]. On the other hand, it indicates that it is not a 
characteristic feature only for generation $Z$, but in this case representatives of generation $\mathrm{Z}$ and generation $\mathrm{X}$ are similar. It seems that in the future, in Poland too, more and more young people will watch matches mainly on devices such as smartphones. Perhaps the high percentage of people using a TV to watch matches results from the way volleyball matches are broadcast in Poland-they are often available on unpaid television channels. Undoubtedly, whether match broadcasts are widely available on TV or online, and whether one has to pay for them on a given device, affects the popularity of the device.

Furthermore, the vast majority of respondents said that the whole matches are still the most attractive content for them. It should be noted, however, that among the younger generations the percentage was about 10 percentage points lower than among the older generations. Interestingly, representatives of the younger generations also stated that behind-the-scenes events are relatively interesting, whereas among older generations this type of content was considered interesting only by a few individuals. Many people find that young people are less patient, so, for example, watching a full football game of two halves of $45 \mathrm{~min}$ can be too demanding. It should be noted, however, that the specificity of volleyball is different as the game lasts until three sets are won by one team (each up to 25 points). As in tennis, there is no specific time to play, and a match can last from less than an hour (in the case of a clear advantage for one team) to more than two hours (when the match is even). Therefore, the results in this study may be different than, for example, among football fans. In some sports, what changes to introduce to make the game more attractive are discussed. Therefore, it might be worth checking if some volleyball solutions could be employed.

The results of the research confirmed the presence of some global trends in the consumption of sports products. On the other hand, the results indicate that the specificity of a given market may play an important role in shaping consumption patterns. Previous studies have shown that younger generations are less likely to watch matches on TV compared to other devices. The results of the survey conducted with respondents from Poland showed that these differences are not significant. Each market also has its characteristics, which should be taken into account in subsequent studies.

\section{Conclusions}

Nowadays, digital transformation covers all sectors of the economy. Since the number of people who were born in the digital world is continuously growing, the sports industry must adapt properly to continue to develop. Otherwise, it may face a difficult period. In this study, we were able to confirm that the representatives of different generations consume sports products differently, using the example of volleyball fans.

The study showed a strong dominance of digital media over traditional media as the main source of information for fans. In fact, in every generation the press and television were the least frequently used media to obtain information about sports. Progressing digitization could even eliminate these channels as sources of information. The results also indicate that social media are becoming increasingly important in sports, especially for younger generations. Reports cited in this article pointed to the dominance of highlights/short-form content and team/athlete-generated content over the whole game [1,4]. However, our study showed that inn the Polish market these products are much less attractive than the whole game. This may be related to the low popularity of using computers, tablets, and smartphones to watch sports. Representatives of all generations in Poland still most often use TV to watch matches, but almost $20 \%$ of Generation $\mathrm{Y}$ and $\mathrm{Z}$ also use computers and smartphones. Given the above, it should be stated that the digital transformation undoubtedly has an impact on the sports industry. Today every sports organization must have and actively use social media to communicate with fans. Also, sports clubs need to provide content different than whole games if they want to maintain or increase the number of their fans. Undoubtedly, digital transformation in the future will bring many challenges and opportunities for the sports industry, and club representatives will have to react accordingly. 
However, the presented results are characterized by some limitations. First of all, it is not known if the same trends occur also in other countries and among fans of sports other than volleyball. The analysis also focused only on three aspects of digital transformation. Therefore, subsequent research in this area should take the above-mentioned into account and verify whether such trends also occur in other countries, for other sports and affecting other factors of digitization.

Author Contributions: Conceptualization, M.L., A.M. and A.R.; methodology, M.L.; formal analysis, A.M.; data curation, M.L. and A.M.; writing-original draft preparation, A.R.; writing-review and editing, A.R., A.M. and M.L.; funding acquisition, M.L. and A.M. All authors have read and agreed to the published version of the manuscript.

Funding: The study was conducted within the research project Economics in the face of the New Economy financed within the Regional Initiative for Excellence programme of the Minister of Science and Higher Education of Poland, years 2019-2022, grant no. 004/RID/2018/19, financing 3,000,000 PLN

Institutional Review Board Statement: The study was conducted according to the guidelines of the Declaration of Helsinki, the recommendations of the Ethics Committee at the Poznan University of Economics and Business and the recommendations of the National Science Center in Poland, which can be found at: https://ue.poznan.pl/en/badania-naukowe-uep,c458/komisja-ds-etykibadan-naukowych, a60579.html. Our research was conducted in the form of an online survey. The well-being of the respondents was our supreme value, and the conducted research did not in any way infringe the dignity, well-being, and fundamental rights and autonomy of the people participating in the research.

Informed Consent Statement: Informed consent was obtained from all subjects involved in the study.

Data Availability Statement: The data were obtained through our own empirical research based on primary data. The acquired data are in the possession of the authors of the study.

Conflicts of Interest: The authors declare no conflict of interest. The funders had no role in the design of the study; in the collection, analyses, or interpretation of data; in the writing of the manuscript, or in the decision to publish the results.

\section{References}

1. PricewaterhouseCoopers. Sports Industry: Lost in Transition? 2018. Available online: https://www.pwc.ch/en/publications/20 18/PwCSportsSurvey-2018_web.pdf (accessed on 17 September 2021).

2. Hölig, S.; Hasebrink, U. Reuters Institute Digital News Report 2020. 2020, p. 73. Available online: www.leibniz-hbi.de (accessed on 17 September 2021).

3. Grzeszak, J. Modele biznesowe mediów po pandemii; Polski Instytut Ekonomiczny: Warszawa, Poland, 2021.

4. PricewaterhouseCoopers. PwC's Sports Industry: System Rebooting; PricewaterhouseCoopers: London, UK, 2020. Available online: https: / library.olympics.com/Default/doc/SYRACUSE/470563/sport-industry-system-rebooting-pwc-s-sports-survey2020-pricewaterhousecoopers?_lg=en-GB (accessed on 10 September 2021).

5. Silverman, A. The Sports Industry's Gen Z Problem: Fewer Fans, Lower Viewership; Morning Consult: Washington, DC, USA, 2020.

6. da Silva, E.C.; las Casas, A.L. Sport fans as consumers an approach to sport marketing. Br. J. Mark. Stud. 2017, 5, 36-48.

7. Yim, B.H.; Byon, K.K.; Baker, T.A.; Zhang, J.J. Identifying critical factors in sport consumption decision making of millennial sport fans: Mixed-Methods approach. Eur. Sport Manag. Q. 2021, 21, 484-503. [CrossRef]

8. Złotnicki, A.; Złotnicki, R. Transformacja Cyfrowa w Polskich Klubach Piłkarskich; Akademia Leona Koźmińskiego: Warszawa, Poland, 2019.

9. Capgemini Research Institute. Emerging Technologies in Sports Reimagining the Fan Experience; Capgemini Research Institute: Paris, France, 2019. Available online: https:/ / www.capgemini.com/pl-pl/raporty/emerging-technologies-in-sports/ (accessed on 10 November 2021).

10. Bridge, G. The Changing Face of Sports Fandom-Variety. 2021. Available online: https://variety.com/vip/the-changing-faceof-sports-fandom-1234920561/ (accessed on 17 September 2021).

11. Kagermann, H.; Wahlster, W.; Helbig, J. Umsetzungsempfehlungen für das Zukunftsprojekt Industrie 4.0: Deutschlands Zukunft als Produktionsstandort Sichern (Abschlussbericht des Arbeitskreises Industrie 4.0); Acatech-Deutsche Akademie der Technikwissenschaften: Frankfurt, Germany, 2013.

12. Ghobakhloo, M. Industry 4.0, digitization, and opportunities for sustainability. J. Clean. Prod. 2019, 252, 119869. [CrossRef]

13. Jankowska, B.; Götz, M.; Tarka, P. Foreign subsidiaries as vehicles of industry 4.0: The case of foreign subsidiaries in a posttransition economy. Int. Bus. Rev. 2021, 30, 6. [CrossRef] 
14. Śledziewska, K.; Włoch, R. Gospodarka Cyfrowa. Jak Nowe Technologie Zmieniają Świat; Wydawnictwo Uniwersytetu Warszawskiego: Warszawa, Poland, 2020.

15. Pieriegud, J. Cyfryzacja gospodarki i społeczeństwa-Wymiar globalny, europejski i krajowy. In Cyfryzacja Gospodarki $i$ Społeczeństwa-Szanse i Wyzwania dla Sektorów Infrastrukturalnych; Gajewski, J., Paprocki, W., Pieriegud, J., Eds.; Publikacja Europejskiego Kongresu Finansowego: Gdańsk, Poland, 2016.

16. Grzejek, K. Exaco. 2020. Available online: https://exaco.pl/digitalizacja-a-cyfryzacja-czym-sie-one-roznia/ (accessed on 17 September 2021).

17. Zalewski, J. Dyskusja.biz-Blogi o biznesie, artykuły biznesowe. 2016. Available online: https://dyskusja.biz/gospodarka/ digitalizacja-jest-koniecznoscia-55309 (accessed on 16 September 2021).

18. Dimock, M. Where Millennials End and Generation Z Begins. 2019. Available online: https://www.pewresearch.org/fact-tank/ 2019/01/17/where-millennials-end-and-generation-z-begins/ (accessed on 17 September 2021).

19. Velički, D.; Velički, V. Characteristics and particularities of educating the net-generation. In The 2015 WEI International Academic Conference Proceesdings; The West East Institute: Prag, Czech Republic, 2015; pp. 109-120.

20. Kolnhofer-Derecskei, A.; Reicher, R.Z.; Szeghegyi, A. The X and Y generations' characteristics comparison. Acta Polytech. Hung. 2017, 14, 107-125. [CrossRef]

21. Rojewska, M. Milenialsi, Pokolenie Z, Y, X, Generacja Baby Boomers—kto to? 2021. Available online: https://interviewme.pl/ blog/pokolenie-z (accessed on 17 September 2021).

22. Dionísio, P.; Leal, C.; Moutinho, L. Fandom affiliation and tribal behaviour: A sports marketing application. Qual. Mark. Res. 2008, 11, 17-39. [CrossRef]

23. McCarthy, J.; Rowley, J.; Ashworth, C.J.; Pioch, E. Managing brand presence through social media: The case of UK football clubs. Internet Res. 2014, 24, 181-204. [CrossRef]

24. Tapp, A.; Clowes, J. From 'carefree casuals' to 'professional wanderers. Eur. J. Mark. 2002, 36, 1248-1269. [CrossRef]

25. Metelski, A. Marketing sportowy na przykładzie koszykówki. Mark. Rynek. 2017, 1, 11-19.

26. Vale, L.; Fernandes, T. Social media and sports: Driving fan engagement with football clubs on Facebook. J. Strateg. Mark. 2018, 26, 37-55. [CrossRef]

27. Prensky, M. Digital Natives, Digital Immigrants. Horizon. 2001, 9, 1-6.

28. Tatiana, F.; Carvalho, P.G. Media influence on elite football performance: A literature review to develop a model. J. Phys. Educ. Sport 2018, 18, 1980-1985. [CrossRef]

29. Nessel, K. Rynek i produkt sportowy. In Przedsiebiorczość w Sporcie Zasady i Praktyka; CeDeWu: Warszawa, Poland, 2016 ; pp. 65-73.

30. Constantinescu, M. The Specifics of the Sport Product and Their Implications within the Marketing Activity. Int. J. Econ. Pract. Theor. 2011, 1, 71-76.

31. Popović, S. Contemporary sports product and making a brand. Exerc. Qual. Life 2017, 9, 37-41. [CrossRef]

32. Ungerman, O.; Dědková, J. Marketing innovations in Industry 4.0 and their impacts on current enterprises. Appl. Sci. 2019, 9, 3685. [CrossRef]

33. Xiao, X.; Hedman, J.; Tan, F.T.; Tan, C.W.; Lim, E.T.; Clemenson, T.; Henningsson, S.; Mukkamala, R.R.; Vatrapu, R.; Hillegersberg, J.V. Sports Digitalization: An Overview and A Research Agenda. In Proceedings of the 38th International Conference on Information (ICIS) 2017, Seoul, Korea, 10-13 December 2017; Association For Information System: Atlanta, GA, USA, 2018.

34. Deloitte. A Whole New Ball Game Navigating Digital Change in the Sports Industry. 2018. Available online: https://www2 .deloitte.com/content/dam/Deloitte/us/Documents/technology-media-telecommunications/us-digital-transformationsports.pdf (accessed on 10 September 2021).

35. Leszczyński, M.; Metelski, A. The social media activity of top athletes during the global suspension of sports competitions-Based on the example of instagram. Mark. Rynek 2021, 4, 10-17. [CrossRef]

36. WorldofVolley. WorldofVolley: In Which Countries Is Volleyball Most Popular? 2020. Available online: https:/ / worldofvolley. com/latest_news/111980/in-which-countries-is-volleyball-most-popular.html (accessed on 16 September 2021).

37. Sadowski, R. Raport Newspoint: Pokolenia w Polsce i potrzeba monitorowania ich rosnacej aktywności. 2018. Available online: https://www.newspoint.pl/blog/raport-newspoint-pokolenia-w-polsce-i-potrzeba-monitorowania-ich-rosnacej-aktywnosci (accessed on 29 November 2021). 